STUDIA POLONIJNE

DOI: $\frac{\text { T. } 42 \text { LUBLIN } 2021}{\text { ht/doi.org/10.18290/sp2 } 142.5}$

RENATA LESIAKOWSKA

\title{
STACJA MISYJNA „POLONIA” W TRANSWALU (1885-1914) NA PODSTAWIE PRASY KOŚCIOŁA EWANGELICKO- -AUGSBURSKIEGO W KRÓLESTWIE POLSKIM
}

Wiek XIX to czas upowszechniania się w społeczeństwach chrześcijańskich idei Kościoła misyjnego. Szeroki zakres inicjatyw chrystianizacyjnych związany był ściśle z europejską ekspansją kolonialną, a wśród rozszerzających swoje panowanie mocarstw najsilniejszą pozycję zyskało imperium brytyjskie $^{1}$. Wyprawy docierające $\mathrm{w}$ najdalsze zakątki świata zabierały ze sobą misjonarzy, zazwyczaj należących do tego samego nurtu chrześcijaństwa co organizatorzy ekspedycji. Z drugiej zaś strony bardzo często, jak ujął to Henryk Zins, „krzyż zjawiał się przed flagą”, a misje torowały drogę administracji państwowej ${ }^{2}$.

Kościoły protestanckie powoływały do życia różnorodne instytucje misyjne, które działając przez dziesięciolecia wypracowały skuteczne modele organizacyjne. Na zaangażowanie finansujących te inicjatywy wiernych wpływało zjawisko tzw. przebudzeń, czyli dążenie do odnowienia życia chrześcijańskiego w myśl zasad ewangelicznych, które mają być szczerze, osobiście przeżywane $^{3}$. W Kościele luterańskim ruch przebudzeniowy objawiał się nie tylko troską o - jak wówczas mówiono - ludy pogańskie, ale także działalnością

Mgr RENATA LESIAKOWSKA - doktorantka, Uniwersytet Marii Curie-Skłodowskiej; e-mail: ad11@op.pl; ORCID: https://orcid.org/0000-0002-3972-022X.

${ }^{1}$ K.S. Latourette, The Christian missionary movement of the nineteenth and twentieth centurie, „The Catholic Historical Review” 23(1937), nr 2, s.153-159.

${ }^{2}$ H. ZINS, Cecil Rhodes i powstanie protektoratu Beczuany w 1885 roku, „Annales Universitatis Mariae Curie-Skłodowska”, Sectio F, 1997/1998, t. 52/53, s. 225-236.

${ }^{3}$ Terminem „przebudzenie” posługuje się m.in. E. KNEIFEL, Geschichte der EvangelischAugsburgischen Kirche in Polen, Niedermarschacht über Winsen/Luhe 1965, s. 140; E. ALABRUDZIŃSKA, Juliusch Bursche (1862-1942) - zwierzchnik Kościoła ewangelicko-augsburskiego w Polsce. Biografia, Toruń 2010, s. 45. W podobny sposób należy rozumieć pojęcie „ruch pietystyczny”, zob. W. GASTPARY, Historia Kościoła. Okres nowożytny (do pierwszej wojny światowej), Warszawa 1971, s. 278-279. 
na rzecz własnego zboru i społeczeństwa (rozwój szpitali i szkół dla osób niepełnosprawnych, szkółek niedzielnych dla dzieci, nabożeństwa „ewangelizacyjne" zachęcające do stosowania zasad biblijnych w praktyce dnia codziennego). Te dwa nurty aktywności prowadzonej w ramach wspólnot kościelnych nazywano misją zewnętrzną i wewnętrzną ${ }^{4}$. Oczywiście, gotowość do tworzenia placówek misyjnych w podbijanych krajach wynikała nie tylko z pobożności - był to także specyficzny wyraz wzrastającego zainteresowania społeczeństw europejskich odległymi, egzotycznymi kulturami oraz przekonania o misji cywilizacyjnej białego człowieka.

Entuzjazm misyjny podzielali także luteranie zamieszkujący ziemie polskie zaboru rosyjskiego. Utrzymywanie przez nich stacji misyjnej w południowej Afryce jest faktem bardzo mało znanym. W publikacjach polskich odnaleźć można jedynie marginalne wzmianki na temat tej placówki ${ }^{5}$, nieco więcej informacji podał niemiecki historyk Kościoła, pastor Eduard Knei$\mathrm{fel}^{6}$. W znacznej mierze stan ten wynika zapewne z niewielkiej bazy źródłowej, zawierającej z reguły jedynie krótkie, administracyjne informacje. Artykuł ten przedstawia okoliczności powstania oraz sposób funkcjonowania „Polonii” na podstawie doniesień prasy luterańskiej wychodzącej na terenie Królestwa Polskiego. Na wstępie należy jeszcze poświęcić kilka słów samemu Kościołowi ewangelicko-augsburskiemu. Choć reprezentował on zdecydowanie najliczniejszą spośród wszystkich denominacji protestanckich na XIX-wiecznych ziemiach polskich, to jednak w porównaniu z Kościołem katolickim posiadał niewielu członków, co wiąże się z tym, że jego dzieje stosunkowo rzadko przyciągają uwagę badaczy.

${ }^{4}$ E. KNEIFEL, Geschichte der Evangelisch-Augsburgischen..., s. 148-149. Warto zaznaczyć, że darowizny na rzecz obu typów misji wpłacano do jednej kasy misyjnej, zob. „Zwiastun Ewangeliczny" 1900, nr 12, s. 379.

${ }^{5}$ Np. P. Szlanta, Opinia publiczna Królestwa Polskiego wobec wojny burskiej, „Przegląd Historyczny" 91(2000), nr 4, s. 535-550; M. GETKA-KenIG, Antoni Zwoliński, ludwisarz warszawski z przełomu XIX i XX wieku, „Almanach Warszawy” 2020, t. 13, s. 81-100; A. ŻuKowski, Polskie nazwy w Afryce Poludniowej, „Poradnik Językowy” 1996, z. 3, s. 57-63. Ostatni z wymienionych artykułów przytacza wzmiankę o misji „Polonia” w Transwalu, jaką w swoich przeznaczonych do publikacji wspomnieniach zamieścił angielski podróżnik Frederick Young. Twierdził on, że gościł w „Polonii”, nie zdobył jednak rzetelnych informacji na temat misji. Był przekonany, że prowadzą ją rosyjscy misjonarze obrządku greckiego. Stwierdzenie to jest o tyle interesujące, że wskazuje na stan (nie)wiedzy o ziemiach polskich, zarówno samego autora, jak i jego wydawcy.

${ }^{6}$ E. KNEIFEL, Geschichte der Evangelisch-Augsburgischen ..., s. 159-160. Bardzo dużo szczegółowych informacji, niestety nieopracowanych naukowo, podaje potomek misjonarzy pracujących w Transwalu i Natalu, Waldo Penhorn, https://medium.com/@penzhorn.waldo_1942/thehermannsburg-mission-f0a951f5cf04 [dostęp: 26.07.2020]. 
Protestanci w Królestwie Polskim drugiej połowy XIX wieku stanowili niewielką mniejszość, liczącą w kolejnych dziesięcioleciach od około 180 do około 699 tys. osób, co mieściło się w przedziale 4,5-5\% ogółu mieszkańców. W grupie tej zdecydowanie przeważali ewangelicy augsburscy (ponad $90 \%)^{7}$. Ich napływ na ziemie polskie związany był z rozbiorami Rzeczypospolitej, w wyniku których znaczna część omawianego obszaru przypadła Prusom. Migracja $\mathrm{z}$ państw niemieckich trwała także po utworzeniu Księstwa Warszawskiego, przekształconego następnie w Królestwo Polskie, a rządzący wprowadzali regulacje korzystne dla osadników w przekonaniu, że sprowadzanie „użytecznych cudzoziemców” sprzyja rozwojowi gospodarczemu kraju ${ }^{8}$. Początkowo zdecydowanie niemiecki charakter Kościoła ewangelicko-augsburskiego stopniowo zmieniał się, w kolejnych dekadach w coraz większej liczbie zborów prowadzono posługę zarówno w języku niemieckim, jak i polskim. Procesy asymilacyjne najszybciej zachodziły w Warszawie. Kres rozwojowi społeczności luterańskiej na ziemiach polskich zaboru rosyjskiego położył wybuch I wojny światowej. Władze rosyjskie wywiozły wówczas w głąb Rosji znaczną część wiernych, zwłaszcza z terenów wiejskich. Z punktu widzenia administracji carskiej stanowili oni potencjalnych sojuszników niemieckich, niemniej $\mathrm{w}$ praktyce do uchodźstwa ${ }^{9}$ zmuszane były także rodziny spolonizowane oraz niektórzy pastorzy broniący parafian bez względu na podziały na tle narodowościowym. Części wywiezionych udało się powrócić do Polski, jednak wybuch II wojny światowej, a następnie uwarunkowania powojenne skutkowały zdziesiątkowaniem społeczności luterańskiej na ziemiach polskich ${ }^{10}$.

Informacje o rozwoju ruchu misyjnego w Kościołach protestanckich docierały na ziemie polskie za pomocą prasy ewangelickiej. $\mathrm{Na}$ terenie

${ }^{7}$ W. Pruss, Społeczeństwo Królestwa Polskiego w XIX i początkach XX wieku, cz. 1, Narodowości, wyznania, sekty, organizacje kościelne, „Przegląd Historyczny” 68(1977), nr 2, s. 259-288.

${ }^{8}$ P. SzKUTNIK, Sprowadzanie użytecznych cudzoziemców. Osadnicy w zachodniej części Królestwa Polskiego w pierwszej połowie XIX wieku na przykładzie przodków autora, „Kwartalnik Historii Kultury Materialnej” 2013, nr 3, s. 409-422.

9 Termin „uchodźstwo” na określenie przymusowej migracji mieszkańców ziem polskich w głąb Rosji w czasie I wojny światowej stosują np. M. KorZENIOwsKi, K. LATAwIEC, D. TARASIUK, Uchodźstwo polskie w Rosji w latach I wojny światowej w świetle dokumentów, Lublin 2018.

${ }^{10}$ Jarosław Kłaczkow podaje, że w 1957 r. Kościół ewangelicko-augsburski liczył 122125 wiernych, jednak statystyka ta obejmuje także Ziemie Odzyskane; liczba ta zresztą szybko malała. J. KŁACZKOw, Kościót Ewangelicko-Augsburski w Polsce w latach 1945-1989, [w:] Kościoły luterańskie na ziemiach polskich (XVI-XX w.), t. III: W ramach Rzeczpospolitej, państw ościennych $i$ na emigracji, red. J. Kłaczkow, Toruń 2012, s. 175-219; E. ALABRUDZIŃSKA, Juliusz Bursche..., s. 49-56. 
Królestwa ukazywały się takie czasopisma, jak „Zwiastun Ewangeliczny” (1863-1882, 1898-1914), „Evangelisch Luterisches Kirchenblatt” i jego odpowiednik wydawany $\mathrm{w}$ języku polskim, zatytułowany „Głosy Kościelne w sprawie Kościoła Ewangelicko-Augsburskiego” (1884-1913) oraz „Unsere Kirche" (1906-1920), pismo stanowiące organ prasowy naczelnych władz Kościoła ${ }^{11}$. Idee misyjne propagowali także duchowni, w tym władze kościelne. Wymienić tu należy m.in. generalnego superintendenta Paula von Everth, a ze znanych pastorów Leopolda Otto, Rudolfa Gundlacha oraz Wilhelma Piotra Angersteina ${ }^{12}$. Między innymi dzięki osobistym kontaktom ostatniego z wymienionych $\mathrm{z}$ przedstawicielami misji hermannsburskiej ${ }^{13}$ możliwe stało się utworzenie przez Kościół Ewangelicko-Augsburski w Królestwie Polskim placówki misyjnej w Transwalu. Wstępne porozumienie z misją, w myśl którego Kościół w Polsce zobowiązywał się przekazywać corocznie przynajmniej 1000 rubli na rzecz stacji, zostało zawarte w $1882 \mathrm{r}$. Kontrakt pomiędzy misją a Kościołem Ewangelicko-Augsburskim w Królestwie Polskim ze strony polskiej podpisał w 1885 r. superintendent Gustaw Manitius. Pierwszy misjonarz, pochodzący z Rygi, Friedrich Eugen Teichmann przybył na teren „Polonii” prawdopodobnie już 3 stycznia 1883 r. $^{14}$

${ }^{11}$ J. KŁACZKOw, Protestanckie wydawnictwa prasowe na ziemiach polskich w XIX i pierwszej połowie XX wieku, Toruń 2008, s. 16-71.

12 Tytuł generalnego superintendenta przysługiwał zwierzchnikowi Kościoła ewangelicko-augsburskiego w danym kraju. Paul von EVERTH (1812-1895) urodził się w okolicy Dorpatu (obecnie Tartu w Estonii). Na stanowisko generalnego superintendenta Kościoła ewangelicko-augsburskiego w Królestwie Polskim został powołany w 1875 r. Zmarł w Warszawie. Leopold OTто (1819-1882) pochodził ze spolonizowanej rodziny warszawskich ewangelików (jej przedstawiciele brali udział w wojnach napoleońskich oraz powstaniu listopadowym), związany był z warszawską parafią Świętej Trójcy. Rudolf GundLACH (1850-1922) pracował w kilku miejscowościach, najdłużej w parafii Świętej Trójcy w Łodzi, gdzie rozwinął aktywną działalność dobroczynną. Wieloletnim pierwszym pastorem w tej samej parafii był Wilhelm Piotr ANGERSTEIN (1848-1928), wydawca polsko- i niemieckojęzycznego czasopisma kościelnego. J. SosnowsKA, Działalność duszpasterska i społeczna pastora Rudolfa Gustawa Gundlacha (1850-1922). Przyczynek do historii dobroczynności w Łodzi, „Studia z Historii Społeczno-Gospodarczej XIX i XX Wieku” 10(2012), s. 87-103; E. KNEIFEL, Die Pastoren der Evangelisch-Augsburgischen Kirche in Polen, Eging 1968, s. 97-99, 144-146; E. KNEIFEL, Geschichte der Evangelisch-Augsburgischen ..., s. 159-160.

${ }^{13}$ Misja hermannsburska została utworzona w 1850 r., początkowo działała w ramach Ewangelicko-Luterańskiego Kościoła Krajowego Hanoweru. Pierwsi misjonarze zostali wysłani w 1854 r. do Afryki Południowej. Założycielem misji był Ludwik Harms; uczniów szkoły misyjnej kształcono w duchu tradycyjnych zasad luterańskich. W. Proske, Zur politischen Bedeutung der Hermannsburger Mission in Botswana, „Zeitschrift für Religions- und Geistesgeschichte” 41(1989), nr 3, s. 248-259; Ludwik Harms, „Zwiastun Ewangeliczny” 1870, nr 5, s.104-110.

${ }^{14}$ Datę tę, jako dzień założenia stacji podaje A. BECHTLE, Eindrücke und Wahrnehmungen eines Gastes des Missionars Teichmanns auf der Station Polonia, „Evangelisch-lutherisches Kirchenblatt" 1886 , nr 1, s. 5-7. Informacje o zawarciu porozumienia i podpisaniu kontraktu za: 
W ten sposób przedstawiały się uwarunkowania powstania misji „Polonia" po stronie społeczności wysyłającej misjonarzy. Równie ciekawa i niezwykle skomplikowana była sytuacja w kraju, w którym stacja misyjna miała powstać. Był on zamieszkany przez rdzenne i napływowe ludy afrykańskie (z grupy Bantu oraz grup nazywanych wówczas Hotentotami i Buszmenami), Burów ${ }^{15}$ oraz XIX-wiecznych białych osadników, głównie angielskich i niemieckich. Państwowość Transwalu, nazywanego także Republiką Południowoafrykańską (obie te nazwy w różnych okresach miały oficjalny status), zaczęła się kształtować w latach trzydziestych XIX wieku wskutek tzw. Wielkiego Treku. Termin ten oznacza przesiedlanie się rodzin burskich z Kraju Przylądkowego na północ. Przyczyną wędrówki - oprócz poszukiwania rozległych pastwisk dla bydła po porzuceniu coraz mniej opłacalnej uprawy pszenicy i winogron - były konflikty z Anglikami i lokalnymi plemionami. Sprzeczności interesów znalazły wyraz w sprawie niewolnictwa; burscy farmerzy, którzy zobowiązali się do jego zniesienia, nie otrzymali obiecanego przez Anglików odszkodowania ani gwarancji bezpieczeństwa ze strony władców plemiennych ${ }^{16}$. Migranci osiedlali się na terenach położonego pomiędzy rzekami Vaal a Limpopo Transwalu, także Natalu znajdującego się na południe od rzeki Tugela oraz dzisiejszej Oranii. Zdobycie tych ziemi wiązało się z walkami z ludnością tubylczą - choć trzeba zauważyć, że większość terenów, na których chcieli osiedlić się Burowie, została przez nich odkupiona bądź opustoszała wskutek długotrwałych wojen plemiennych - a następnie kampanią na rzecz uznania przez Wielką Brytanię niezależności Afrykanerów ${ }^{17}$. Wypracowane $\mathrm{z}$ Londynem porozumienie straciło w praktyce swoją moc w momencie odkrycia na omawianych obszarach złóż złota i diamentów. Także coraz silniej docierające do brytyjskich polityków głosy, przekonujące, że kontrola nad tym terenem jest niezbędna do ochrony interesów imperium $\mathrm{w}$ tej części Afryki ${ }^{18}$, nie sprzyjały ustabilizowaniu się

E. KNEIFEL, Geschichte der Evangelisch-Augsburgischen..., s. 159-160. W tytule artykułu przyjęto datowanie za E. Kneiflem.

${ }^{15}$ Burowie byli potomkami białych osadników z XVII wieku, głównie wyznawców kalwinizmu, pochodzących z terenów dzisiejszej Holandii. Sami Burowie określali się w omawianym okresie mianem Afrykanerów; nazwa ta upowszechniła się w państwach europejskich pod koniec XIX wieku. G. BĘBNIK, Ostatnia walka Afrykanerów, Biała Podlaska 2004, s. 42-77.

${ }^{16}$ Tamże, s. 46-52.

${ }^{17}$ R. MATERA, Taktyka prezydenta Paulusa Krugera wobec Wielkiej Brytanii w latach 18831890, „Acta Universitatis Lodziensis. Folia Historica” 1999, t. 65, s. 31-49; G. BĘBNIK, Ostatnia walka..., s. 36-51.

${ }^{18}$ H. ZINS, Cecil Rhodes. Ekspansja brytyjska w Afryce pod koniec XIX wieku, Gdańsk 2000, s. $122-148$. 
sytuacji. Transwal sąsiadował z innymi republikami burskimi, koloniami (protektoratami) brytyjskimi, państwami tubylczymi oraz portugalskim Mozambikiem. Stosunkowo niedaleko znajdowała się Niemiecka Afryka Południowo-Zachodnia.

Przywódcy burscy starający się o skonsolidowanie różnorodnych grup potomków XVII-wiecznych osadników odwoływali się do uświęconej historii. Koncentrowała się ona na motywach konfliktu z Brytyjczykami dotyczącego m.in. ich ingerencji $w$ stosunki farmerów $z$ niewolnikami oraz promowała etos walki z lokalnymi plemionami, którą Burowie w swoim przekonaniu musieli prowadzić samotnie, bez wsparcia ze strony administracji państw europejskich. „Naród nie życzy sobie równości pomiędzy białymi i kolorowymi mieszkańcami w państwie i kościele" - głosił 9 artykuł uchwalonej w latach osiemdziesiątych XIX wieku konstytucji Transwalu. Te elementy tradycji Afrykanerów nie sprzyjały oczywiście ich sympatii do misji, nastawionych na podmiotowe traktowanie ludności tubylczej. Jednak na korzyść inicjatywy podjętej przez Kościół Ewangelicko-Augsburski w Królestwie Polskim działało to, że misje organizowane przez ośrodki niemieckie stanowiły w oczach burskich przywódców przeciwwagę dla angielskich, ponadto były jeszcze jedną płaszczyzną korzystnie rozwijającej się współpracy z Niemcami ${ }^{19}$. Na terenach nabytych przez Kościół zamieszkiwały plemiona Tswana (należące do grupy Bantu); w omawianym okresie europejską nazwę tych plemion w języku polskim tłumaczono jako Beczuanie. Najstarsze zachowane przekazy plemienne dotyczące tego ludu datowane są na przedział pomiędzy XII a XV wiekiem, od XVI stulecia Tswana zamieszkiwali wioski na terenie późniejszego Transwalu, a potrzeba kontroli stad bydła stanowiła płaszczyznę do budowania silniejszej władzy niektórych wodzów - królów. Zarówno ze względu na ciągłe walki, jak i sposób gospodarowania plemiona Tswana nieustannie zmieniały miejsce osiedlenia ${ }^{20}$.

Zorganizowanie misji w tych okolicznościach z pewnością nie było zadaniem łatwym. Obszerną relację dotyczącą początków jej funkcjonowania zamieścił w 1886 r. „Evangelisch-Lutherisches Kirchenblatt”. Autor artykułu, podpisujący się jako A. Bechtle (geodeta rządowy), odwiedził „Polonię” pod koniec 1885 r. Przede wszystkim zwrócił uwagę, że Kościół ulokował stację w bardzo korzystnym miejscu, a także dokonał trafnego wyboru pierwszego misjonarza - Friedricha Eugena Teichmanna ${ }^{21}$. „Polonia” położona

\footnotetext{
${ }^{19}$ Por. W. Proske, Zur politischen Bedeutung..., s. 248-259.

${ }^{20}$ H. ZINS, Cecil Rhodes. Ekspansja brytyjska w Afryce..., s.122-123.

${ }^{21}$ Imiona misjonarza Teichmanna por. https://www.safrika.org/Names/HmbMissS-Z.html [dostęp: 17.11.2020].
} 
była na dobrze nawodnionym, żyznym terenie (w dorzeczu Limpopo), pomiędzy Pretorią a Rustenburgiem ${ }^{22}$. Rozciągające się na południe od stacji pasmo wzgórz chroniło ją przed silnymi prądami atmosferycznymi, a wyżynne położenie - przed rozprzestrzenianiem się chorób. Jeśli chodzi natomiast o pastora Teichmanna, miał on dzięki swoim cechom charakteru, energii i zapałowi bardzo dobrze wywiązać się z zadania założenia placówki „od zera”. W ciągu dwóch lat udało mu się wybudować (niewielki) budynek kościoła i dom misyjny oraz zainteresować chrześcijaństwem i zachęcić do zamieszkania i pracy na terenie „Polonii” 65 osób, które osiedliły się w „czystych i miłych” chatkach. Mieszkańcy utrzymywali się z uprawy (m.in. kukurydzy) oraz hodowli bydła. Co ciekawe, zwykle niechętni misjom Burowie, zdaniem autora relacji, odnosili się życzliwie do powstającej placówki ${ }^{23}$; również król plemienny Zambok, pomimo że nie przyjął chrztu, był jej przychylny (miało to wynikać z nadziei na pomoc misjonarzy w kontaktach z władzami Transwalu).

Dzień powszedni mieszkańców „Polonii” przebiegał według ustalonego schematu. Przed godziną szóstą kończono śniadanie oraz poranne nabożeństwo i rozpoczynała się całodzienna praca (uprawa i hodowla, obok wsparcia finansowego udzielanego przez ewangelików Królestwa Polskiego, stanowiły materialną podstawę funkcjonowania stacji). Wieczorem odbywała się wspólna modlitwa, a już o godzinie dziesiątej mieszkańcy stacji pogrążeni byli w głębokim śnie. Inaczej przebiegały dni świąteczne. Bardzo uroczyście obchodzono zwłaszcza dzień przyjęcia chrztu, który po wielogodzinnych modlitwach i śpiewach kończył się wspólnym ucztowaniem. Uwagę autora relacji zwróciło, że nowo ochrzczeni nie życzyli sobie, aby w tej ostatniej części spotkania brali udział ich nienawróceni krewni. Należy jednak zaznaczyć, że okoliczna ludność niechrześcijańska pozostawała z mieszkańcami misji w dobrych relacjach, co wynikało m.in. z tego, że „Polonia” była miejscem, w którym rozdawano lekarstwa, a także służono pomocą w różnych trudnych sytuacjach.

\footnotetext{
${ }^{22}$ Według autora artykułu stacja znajdowała się w równej odległości pomiędzy tymi dwoma miastami; natomiast z mapy wydanej przez misję hermannsburską (prawdopodobnie nie później niż w 1902 r. - oznaczono Wolne Państwo Orania) wynika, że znajdowała się mniej więcej w 2/3 drogi z Rustenburga do Pretorii; jest to jednak tylko pozorna rozbieżność, ponieważ A. Bechtle podał odległość w dniach drogi. A. BECHTLE, Eindrücke und Wahrnehmungen eines Gastes..., nr 1, s. 5-7; $\mathrm{nr}$ 2, s.14-15; Hermannsburger und Bleckmarer Betchuanen- Mission in Transvaal, Missionshandlung Hermannsburg, [brw], https://www.safrika.org/Pics/Tvl-map-01.gif [dostęp: 18.11.2020].

${ }^{23}$ Jak jednak można sądzić z komentarzy w „Zwiastunie Ewangelicznym” zamieszczonych na początku II wojny burskiej, ten pozytywny stosunek nie trwał zbyt długo. E.H.S., Wspótczucie uciśnionym, „Zwiastun Ewangeliczny” 1899, nr 11, s. 328-330; P. SzLANTA, Opinia publiczna Królestwa..., s. 535-550.
} 
Jako świadectwo mentalności XIX-wiecznych Europejczyków wypada jeszcze dodać, że A. Bechtle zaznaczył, iż twarze mieszkańców terenów, na których usytuowano „Polonię”, „nie są brzydkie”. Dzisiejszego czytelnika mogłaby zdziwić wzmianka na temat urody podopiecznych misji, jednak odmienny wygląd ludów zamieszkujących kraje kolonialne wzbudzał w tamtej epoce żywe zainteresowanie i stanowił częsty przedmiot uwag, niejednokrotnie zresztą nieprzychylnych ${ }^{24}$. Kolejną obserwacją o charakterze etnograficznym zawartą $\mathrm{w}$ omawianym artykule było stwierdzenie o muzykalności Beczuanów oraz ich z reguły pokojowym nastawieniu. A. Bechtle przekaza1 także czytelnikom, że mieszkańcy misji ubierają się po europejsku ${ }^{25}$.

Uzupełniając obraz życia „Polonii” trzeba dodać, że ewangelickie stacje misyjne, w tym „Polonia”, prowadziły szkoły dla konfirmantów ${ }^{26}$. Wynikało to $\mathrm{z}$ tradycyjnego $\mathrm{w}$ luteranizmie wymogu opanowania przed przystąpieniem do konfirmacji umiejętności czytania i pisania. Przypuszczalnie jednak zorganizowanie nauczania było możliwe dopiero w kolejnych latach funkcjonowania misji, stąd brak informacji na ten temat w przytoczonej relacji. Pojawia się pytanie, w jakim języku nauczano w „Polonii”. Mógł być to niemiecki lub angielski ${ }^{27}$. Trudno natomiast przypuszczać, aby był to język polski, w Afryce nieprzydatny.

W charakterze ciekawostki warto wspomnieć, że dzwon do budynku kościelnego wybudowanego na terenie stacji zamówiono w renomowanych zakładach warszawskiego ludwisarza Antoniego Zwolińskiego (przedsiębiorstwo to realizowało m.in. zamówienia dla klasztoru Paulinów na Jasnej Górze, katedry w Kaliszu, katedry w Lublinie) ${ }^{28}$, a ufundował go Emil Wedel. Dzwon ważył 514 funtów, wyryto na nim napis: „Gloria in excelsis Deo. Chwała Bogu na wysokościach. Dla stacyi misyjnej ewangelickiej Polonia. Dar Emila Wedel z Warszawy. Anno Domini 1886. Lał A. Zwoliński w Warszawie"29.

\footnotetext{
${ }^{24}$ Por. K. Dove, Deutsch Südwestafrika, Berlin 1913, s. 201-204 - uwagi o „europejskim”, „,dowcipnym”, ,inteligentnym” wyrazie twarzy Beczuanów oraz o „odrażającym” wyglądzie Hotentotów (którzy wyrazem twarzy mieli „przypominać Chińczyków”).

${ }^{25}$ Ta ostatnia uwaga wiąże się z zagadnieniem tzw. inkulturacji, czyli zaakceptowaniem przez chrześcijan kultury krajów misyjnych. Trzeba zaznaczyć, że dyskusja na ten temat trwała przez kilka stuleci i dopiero w latach siedemdziesiątych wieku XX zagadnienie przestało budzić kontrowersje. Por. np. J. RÓŻAŃSKI, Główne dziedziny inkulturacji, „Studia Theologica Varsaviensia” 49(2011), nr 2, s. 43-78.

${ }^{26}$ Por. np. Wiadomości z kościoła i ze świata, „Zwiastun Ewangeliczny” 1902, nr 9, s. 284-285.

${ }^{27}$ K. RÜTHER, Der Streit um Englisch als Unterrichtsfach im lutherischen Missionsschulen Südafrikas (1895-1910). Impulse für eine Geschichte, [w:] Mission Global, red. R. Habermas, R. Hölzl, Böhlau 2014, s. 91-110.

${ }^{28}$ M. GetKA-Kenig, Antoni Zwoliński..., s. 81-100.

${ }^{29}$ Wiadomości ze świata i kościoła, „Głosy Kościelne w sprawie Kościoła Ewangelicko-Augsburskiego" 1886, nr 4, s. 31-32.
} 
Relacja A. Bechtla to najbardziej wyczerpujący obraz życia „Polonii”, jaki zamieściła prasa kościelna. Niemniej czytelnicy czasopism ewangelickich mogli wyrobić sobie zdanie na temat blasków i cieni życia stacji także dzięki ogólnym informacjom o misjach protestanckich w różnych rejonach świata, które regularnie publikowano ${ }^{30}$. Pojawiały się także rozważania o tych cechach mentalności - co ciekawe - białych chrześcijan, które utrudniały pracę misjonarzy. I tak na przykład w 1890 r. w „Evangelisch-lutherisches Kirchenblatt" ukazała się relacja pewnego misjonarza płynącego na Czarny Ląd. Na podstawie rozmów z pasażerami statku doszedł on do wniosku, że wielu europejskich chrześcijan nie zna swojej wiary, myli chrystianizację z europejskim wychowaniem, bardzo szybko wydaje negatywne sądy o ludach zamieszkujących Afrykę, nie chcąc bliżej ich poznać. Na udostępnionych mu łamach prasowych przypomniał tym, od których w dużej mierze zależała możliwość prowadzenia misji, czyli sponsorującym je wiernym, że Ewangelia wzywa do głoszenia słowa Bożego wszystkim ludom we wszystkich językach świata ${ }^{31}$.

Rozwijając zasygnalizowane właśnie zagadnienie finansowania placówki trzeba stwierdzić, że hojność wiernych stale wzrastała, co umożliwiło wspieranie „Polonii” większymi sumami, niż określone w kontrakcie 1000 rubli rocznie. W 1905 r. generalny superintendent Juliusz Bursche ${ }^{32}$, pełniący także funkcję referenta ds. misji zewnętrznej, stwierdził:

Dzieckiem synodu jest dalej stacja misyjna Polonja w Afryce południowej, a wraz z objęciem pieczy nad tą stacją budzi się zajęcie misją wśród pogan. Dołączona tabelka wykazuje dowodnie, w jakim stopniu zwiększyła się ofiarność na misję wśród pogan i inne sprawy królestwa Bożego ${ }^{33}$.

\footnotetext{
${ }^{30}$ Np. Krótki pogląd na wzrost kościoła chrześcijańskiego, „Zwiastun Ewangeliczny”1901, nr 5, s.133.

${ }^{31}$ Wie urteilst du öber Heidenmission?, „Evangelisch-lutherisches Kirchenblatt” 1890, nr 21, s. 202-204. Warto tu podkreślić, że XIX-wieczni misjonarze oraz inni zaangażowani działacze kościelni sprzeciwiający się niewolnictwu, segregacji rasowej, czy z szacunkiem traktujący nieślubne dzieci, byli pionierami zmian europejskiej mentalności; por. uwagi o misjach A.S., Rok 1910, „Zwiastun Ewangeliczny” 1911, nr 2, s. 42-47.

32 Juliusz BURSCHE (1862-1942) - pastor pracujący początkowo w Wiskitkach, następnie w warszawskiej parafii Świętej Trójcy. Redaktor „Zwiastuna Ewangelicznego”. Na czele Kościoła stanął w 1904 r. W czasie konferencji wersalskiej aktywnie działał na rzecz przyłączenia do Polski Mazur, Śląska Górnego i Śląska Cieszyńskiego. Po wybuchu II wojny światowej aresztowany przez Gestapo, uwięziony w Sachsenhausen; zmarł w Berlinie. E. AlABRUdziŃSKA, Juliusz Bursche..., s.13-34, 63, 129-138.

${ }^{33}$ Książeczka jubileuszowa, „Zwiastun Ewangeliczny” 1905, nr 11, s. 345-347.
} 
Przykładowo, w roku 1888 ofiary na rzecz misji wynosiły 6626 rubli 23 kopiejki (jest to łączna suma na różne formy działalności misyjnej), z czego wydano nieco ponad $2 / 3^{34}$. W 1897 r. na cele misyjne wśród ludów pogańskich zebrano około 7 tys. rubli, z czego 2500 rubli przekazano na misję hermannsburską, a z kolei ta organizacja przeznaczyła 1510 rubli na pokrycie kosztów funkcjonowania „Polonii”. Natomiast w 1898 r. na „misję zewnętrzną" zebrano 15824 rubli; w tym roku nie odnotowano także ani jednej parafii, która nie przekazała żadnych ofiar na rzecz misji, co zapewne pozostawało nie bez związku z wezwaniem wyrażonym rok wcześniej na łamach żywo interesującego się sprawami misji „Zwiastuna Ewangelicznego" ${ }^{35}$. Największe wpłaty na cele misyjne przekazywała parafia św. Jana w Łodzi, kierowana przez pastora W.P. Angersteina ${ }^{36}$. Warto zauważyć, że ofiary zbierano także wśród dzieci, a informacje o ich wysokości zamieszczano w prasie; w tym wypadku formacyjno-wychowawczy wymiar kolekty wydaje się ważniejszy niż jej efekt finansowy ${ }^{37}$. Przyjął się także zwyczaj zbierania datków na misje wśród uczestników uroczystości weselnych, a także fundowania mieszkańcom „Polonii” prezentów bożonarodzeniowych ${ }^{38}$. Podsumowując wątek finansów, do 1904 r. Kościół Ewangelicko-Augsburski w Królestwie Polskim przekazał na rzecz misji hermannsburskiej ponad 58 tys. rubli, brakuje natomiast pełnych danych od roku 1905, przypuszczalnie jednak sumy te były coraz większe ${ }^{39}$. Jak wynika ze wzmianek zamieszczanych zarówno w polsko-, jak i niemieckojęzycznych czasopismach kościelnych, w ciągu kilkudziesięciu lat istnienia placówki troska o jej potrzeby łączyła różnorodne środowiska ewangelickie. $Z$ pewnością jednak wśród luteranów mieszkających na ziemiach polskich znajdowały się również społeczności z rezerwą bądź niechęcią odnoszące się do omawianej inicjatywy, bądź też do idei mi-

${ }^{34}$ Warszawski Synod ewangelicko-augsburski, „Głosy Kościelne w sprawie Kościoła Ewangelicko-Augsburskiego" 1888, nr 20, s. 158-159.

35 Synod Ewangelicko-Augsburski w roku 1898, „Zwiastun Ewangeliczny” 1898, nr 10, s. 220-224; XX Synod ks. ks. pastorów w Królestwie Polskiem, „Zwiastun Ewangeliczny” 1899, nr 10, s. 300-306.

${ }^{36}$ Statistische Nachrichten aus der Evang.-lutherischen Kirche im Königreich Polen für das Jahr 1892, „Evangelisch-luterisches Kirchenblatt” 1893, nr 6, s. 45; Wykaz ofiar, „Zwiastun Ewangeliczny" 1902, nr 7, s. 216-218.

${ }^{37} \mathrm{~Np}$. W numerze 12 z 1900 r. Redakcja „Zwiastuna...” informuje, że polska szkółka niedzielna zebrała na rzecz „Polonii” 4 ruble 60 kopiejek, a niemiecka 7 rubli 50 kopiejek, s. 377.

38 Wiadomości z kościoła i ze świata, „Zwiastun Ewangeliczny” 1901, nr 1, s. 23; Liebesgaben, „Unsere Kirche” 1912, nr 15, s. 120.

${ }^{39}$ E. KNEIFEL, Geschichte der Evangelisch-Augsburgischen..., s.160. 
syjnej w ogólności. Wydaje się, że był to problem dość powszechny w wielu krajach europejskich ${ }^{40}$.

$\mathrm{Z}$ wielkim niepokojem śledzono sytuację w Transwalu w czasie II wojny burskiej. Już po pierwszych miesiącach działań wojennych „Zwiastun...” podawał za „Hermannsburską gazetą misyjną”:

Niewysłowione są pokusy, w jakie popaść może tutejsza czarna ludność, która jest daleko liczniejszą od wszystkich białych, Anglików, Niemców i Burów razem wziętych. [...] Kościoły i szkoły po wielkiej części zamieniono na lazarety. W Transwaalu podczas wojny nie płaci nikt czynszu, najmu ani procentu. Dowóz żywności ustał zupełnie, żniwo krajowe po wielkiej części zniszczeje, także głód będzie prawie nieuniknionym ${ }^{41}$.

Misjonarze donosili, że rdzenna ludność afrykańska jest częściowo zgorszona wojną między Europejczykami, a częściowo czerpie z niej satysfakcję. Obawiali się, że plemiona afrykańskie odczytają konflikt między białymi jako hasło do powrotu do okrutnych zasad wojen plemiennych, co oznaczało m.in. masowe mordowanie kobiet i dzieci ${ }^{42}$. Wyrażali także troskę o wytrwanie w wierze świeżo nawróconych.

W trakcie wojny burskiej „Polonią” kierował E. Grotherr. W przysłanym przez niego sprawozdaniu, krótko podsumowującym 17-lecie istnienia misji (oraz 10-lecie pracy E. Grotherra, który przybył na stację w 1890 r.), przekazał informacje dotyczące liczby wiernych (1145 ochrzczonych, podczas gdy w 1890 r. było ich 176), nowych filiałów (wsie Rantailane, Klipfontein, Elandsfontein, Sefateng, Broederstroom, Makaung), liczby osób ochrzczonych w zeszłym roku (niespełna 200), ofiar na rzecz misji, obyczajowości (nieco wcześniej informował, że wśród nowo ochrzczonych zdarzają się niestety cudzołóstwa i kradzieże, za które są oni wykluczani ze zboru) i różnych zagadnień bytowych. Redakcja „Zwiastuna...” zwróciła uwagę, że list był ocenzurowany i zapewne $\mathrm{z}$ tego powodu nie zawiera wiadomości o zniszczeniach wojennych ${ }^{43}$. Uwagę tę potwierdził w korespondencji z roku następnego dyrektor misji hermannsburskiej, G. Haccius: „Wiecie z pism mi-

\footnotetext{
${ }^{40}$ Wie urteilst du über Heidenmission?, „Evangelisch-lutherisches Kirchenblatt” 1890, nr 21, s. 202-204.

${ }^{41}$ Z Afryki Poludniowej, „Zwiastun Ewangeliczny” 1900, nr 2, s. 58-59.

42 Tamże.

${ }^{43}$ Wiadomości z Polonii, „Zwiastun Ewangeliczny” 1900, nr 6, s.178-180; por. Wiadomości z kościoła i ze świata, „Zwiastun Ewangeliczny” 1899, nr 8.
} 
syjnych co się dzieje na naszych stacjach w Afryce Południowej. Nędza nasza jest znacznie większą jeszcze, niż nam misjonarze donieść mogą"44.

Materialna baza wielu stacji misyjnych (pola uprawne, ogrody, budynki) uległa zniszczeniu. W momencie spisywania przytaczanej korespondencji 14 misjonarzy pracujących dla misji hermannsburskiej na terenie republik burskich znajdowało się w niewoli, a sześciu zmarło wskutek szerzącej się w czasie wojny febry ${ }^{45}$. W kolejnych miesiącach także pastor E. Grother został zmuszony do opuszczenia swojej placówki i przeniesienia się do Pretorii. Do „Polonii” powrócił 2 lipca 1902 r. Opisując stan stacji stwierdził, że poniosła ona stosunkowo małe straty. Liczba mieszkańców nawet wzrosła do 1440 osób, a katechizowania, nauczania i pilnowania porządku podjął się jeden z ochrzczonych Beczuanów. W bardzo złym stanie znajdowały się pola; kościół, zabudowania gospodarcze oraz dom pastora nie zostały spalone, wymagały jedynie nowych dachów. Znacznie gorszy był natomiast stan placówek filialnych, zwłaszcza w Rietfontein, w pobliżu której zorganizowano obóz wojenny ${ }^{46}$.

Pojawia się tu pytanie, jak polscy ewangelicy ustosunkowywali się do konfliktu między Anglikami a Burami, który wzbudzał duże emocje społeczności międzynarodowej. Paweł Szlanta w artykule dotyczącym oceny wojen burskich stwierdził, że stanowiący głos Polaków - ewangelików „Zwiastun Ewangeliczny" przyjął odmienne stanowisko, niż zdecydowana większość czasopism wychodzących w Królestwie. O ile polska opinia publiczna solidaryzowała się, a nawet do pewnego stopnia utożsamiała z Burami, o tyle redakcja „Zwiastuna...” miała $\mathrm{z}$ większą przychylnością odnosić się do strony angielskiej. Wspomniany autor tłumaczył to tym, że „Zwiastun...” otrzymywał informacje bezpośrednio z „Polonii” i mógł mieć dzięki temu lepszy obraz poczynań obu stron, ponadto dla twórców pisma ważne było, że Anglicy życzliwiej odnoszą się do ludności plemiennej oraz są przychylni rozwojowi misji ${ }^{47}$. Bardziej systematyczna analiza przywoływanego czasopisma wskazuje jednak na konieczność pewnej korekty tego twierdzenia. Rzeczywiście, na początku wojny ukazały się w „Zwiastunie...” artykuły nacechowane sympatią do Anglików, skoncentrowane przede wszystkim na sprawach misji i angielskiej działalności na rzecz zniesienia niewolnictwa. Przyznawano w nich jednak równocześnie, że stroną, która wywołała wojnę, byli

\footnotetext{
${ }^{44}$ Wiadomości z kościoła i ze świata, „Zwiastun Ewangeliczny” 1901, nr 7, s. 222.

45 Tamże; A.S., Rok 1901, „Zwiastun Ewangeliczny” 1902, nr 7, s. 205-209.

46 Wiadomości z kościoła i ze świata, „Zwiastun Ewangeliczny” 1902, nr 9, s. 284-285.

${ }^{47}$ P. Szlanta, Opinia publiczna Królestwa..., s. 535.
} 
Anglicy $^{48}$. Natomiast w 1902 r. pisząc o sytuacji w Transwalu Aleksander Schöneich stwierdził, że Burowie oczyścili się na forum międzynarodowym z zarzutów o obojętność dla sprawy ewangelizacji plemion afrykańskich, przedstawiając dowody na to, że były one niesłuszne; zaś akcje podejmowane przez Anglików nie dają się usprawiedliwić ${ }^{49}$. Podsumowując ten poboczny wątek, z pewnością można stwierdzić, że polscy ewangelicy uważali ten konflikt za gorszący i niepotrzebny oraz że wypowiadali się na ten temat z wręcz zastanawiającą powściągliwością. Uderzające dla współczesnego odbiorcy jest np. lakoniczne odniesienie się do wojennych losów misjonarza E. Grothera. Wobec realiów II wojny burskiej - w czasie której Brytyjczycy tworzyli obozy dla ludności cywilnej, gdzie panował głód i szerzyły się choroby, co skutkowało wysoką śmiertelnością - informacja o przymusowym pobycie w Pretorii domaga się wyjaśnienia, którego jednak brakuje ${ }^{50}$.

Wracając do samej stacji, prasa dostarcza niewielu informacji o jej codziennym życiu po II wojnie burskiej. Jednak systematycznie powtarzające się krótkie notatki wskazują, że sytuacja „Polonii” unormowała się. Potwierdza to także informacja $\mathrm{z}$ roku 1908 o kształceniu przez misję hermannsburską dwóch pochodzących z Królestwa Polskiego kandydatów na misjona$\mathrm{rzy}^{51}$. Bardzo trudne do ustalenia są natomiast losy misji po wybuchu I wojny światowej. Wspominany już badacz dziejów Kościoła ewangelicko-augsburskiego na ziemiach polskich, E. Kneifel, jako datę kończącą jej działalność podaje rok $1914^{52}$. Prawdopodobnie jednak misjonarze przebywali na terenie „Polonii” aż do 1956 r. ${ }^{53}$ Jak można przypuszczać, te rozbieżności dotyczące momentu zakończenia pracy stacji mogą być związane z czasowym lub całkowitym zaprzestaniem jej finansowania przez ciężko doświadczoną $\mathrm{w}$

\footnotetext{
${ }^{48}$ E.H.S., Współczucie uciśnionym..., s. 328-330.

${ }^{49}$ A.S., Rok 1901, „Zwiastun Ewangeliczny” 1902, nr 7, s. 205-209.

${ }^{50}$ Wiadomości z kościoła i ze świata, „Zwiastun Ewangeliczny” 1902, nr 9, s. 284-285.

${ }^{51}$ XXVIII synod ogólny ks. ks. pastorów ew. w Królestwie Polskim, „Zwiastun Ewangeliczny” 1908, nr 11, s. 316-320; Ofiary, „Zwiastun Ewangeliczny” 1909, nr 6, s.192; 1909, nr 9, s. 286.

52 E. KNEIFEL, Geschichte der Evangelisch-Augsburgischen..., taką informację można znaleźć także na stronie Centrum Informacyjnego Kościoła Ewangelicko-Augsburskiego w Polsce, http:// old.luteranie.pl/pl/index.php?D=631 [dostęp: 23.06.2020].

${ }^{53} \mathrm{~W}$. Penzhorn wymienia następujących misjonarzy przebywających w „Polonii” po wybuchu I wojny światowej: Johann F. Niebuhr (do 1917 r.), J. Heinrich Mahnke (1913-1920), P. Heinrich Meyer (1920-1938), R. Theodor Müller (1938-1950), Werner Warnecke (1952-1956), https://medium.com/@penzhorn.waldo_1942/the-hermannsburg-mission-f0a951f5cf04 [dostęp: 23.06.2020].
} 
czasie Wielkiej Wojny społeczność luterańską z byłego zaboru rosyjskiego ${ }^{54}$. Temat ten wymaga jednak odrębnych badań.

Podsumowując, stacja misyjna „Polonia” stanowiła ciekawą inicjatywę wiernych niezbyt licznego na ziemiach polskich Kościoła ewangelicko-augsburskiego. Powstała w okresie coraz większego zaangażowania Kościołów europejskich na rzecz misji, prowadzonych zarówno w krajach niechrześcijańskich, jak i pośród własnego społeczeństwa (działalność charytatywna, inicjatywy mające na celu upowszechnienie znajomości Biblii). Zaangażowanie to skutkowało zmianą mentalności nie tylko mieszkańców obszarów kolonialnych, ale także Europejczyków. Kontakt z egzotycznymi kulturami, podejmowany z powodów innych niż zysk materialny, uczył rozróżniania pomiędzy zasadami wiary a normami kulturowymi, zaś konieczność łączenia działalności misyjnej z dobroczynną uwrażliwiała na potrzeby ludzi, którym $\mathrm{w}$ tamtej epoce niejednokrotnie odmawiano jakichkolwiek praw. Stacja misyjna „Polonia” to także jeden z nielicznych „polskich śladów” w Afryce.

\section{BIBLIOGRAFIA}

\section{Źródla archiwalne}

Archiwum Państwowe w Łodzi

39/288/1 Parafia Ewangelicko-Augsburska św. Trójcy w Łodzi, sygn. 12, Heiden Mission (Quittungen, Briefe)

\section{Prasa}

„Evangelisch-lutherisches Kirchenblatt” 1886-1903

„Głosy Kościelne w sprawie Kościoła Ewangelicko-Augsburskiego” 1888

„Unsere Kirche” 1912

„Zwiastun Ewangeliczny” 1870, 1898-1914

\section{Literatura}

AlABRUdZiŃSKA E., Juliusch Bursche (1862-1942) - zwierzchnik Kościoła ewangelicko-augsburskiego w Polsce. Biografia, Toruń: Wydawnictwo Adam Marszałek 2010.

BęBNik G., Ostatnia walka Afrykanerów, Biała Podlaska: Oficyna Wydawnicza „Rekonkwista” 2004.

Dove K., Deutsch Südwestafrika, Berlin: Wilhelm Süsserott 1913.

${ }^{54}$ Warto wspomnieć, że w okresie międzywojennym cele misyjne w Afryce wspierała łódzka parafia Świętej Trójcy. Archiwum Państwowe w Łodzi, 39/288/1 Parafia Ewangelicko-Augsburska św. Trójcy w Łodzi, sygn. 12, Heiden Mission (Quittungen, Briefe). 
GASTPARY W., Historia Kościoła. Okres nowożytny (do pierwszej wojny światowej), Warszawa: Chrześcijańska Akademia Teologiczna 1971, s. 278-279.

GetKA-KenIG M., Antoni Zwoliński, ludwisarz warszawski z przełomu XIX i XX wieku, „Almanach Warszawy" 2020, t.13, s. 81-100.

KiPLING R., The Collected Poems of Rudyard Kipling, [b.m.w.] 1999.

KŁACZKOw J., Kościół Ewangelicko-Augsburski w Polsce w latach 1945-1989, [w:] Kościoły luterańskie na ziemiach polskich (XVI-XX w.), t. III: W ramach Rzeczpospolitej, państw ościennych i na emigracji, red. J. Kłaczkow, Toruń: Wydawnictwo Adam Marszałek 2012, s.175-219.

KŁACZKOw J., Protestanckie wydawnictwa prasowe na ziemiach polskich w XIX i pierwszej połowie XX wieku, Torun: Wydawnictwo Adam Marszałek 2008.

Korzeniowski M., Latawiec K., TARAsiuk D., Uchodźstwo polskie w Rosji w latach I wojny światowej w świetle dokumentów, Lublin: Wydawnictwo Uniwersytetu Marii Curie-Skłodowskiej 2018.

KNeIFEl E., Geschichte der Evangelisch-Augsburgischen Kirche in Polen, Niedermarschacht über Winsen/Luhe: Selbstverlag 1965.

KneIfel E., Die Pastoren der Evangelisch-Augsburgischen Kirche in Polen, Eging: Selbstverlag des Verfassers 1968.

Latourette K.S., The Christian missionary movement of the nineteenth and twentieth centurie, „The Catholic Historical Review” 23(1937), nr 2, s.153-159.

Matera R., Taktyka prezydenta Paulusa Krugera wobec Wielkiej Brytanii w latach 1883-1890, „Acta Universitatis Lodziensis. Folia Historica” 1999, t. 65, s. 31-49.

Proske W., Zur politischen Bedeutung der Hermannsburger Mission in Botswana, „Zeitschrift für Religions- und Geistesgeschichte" 41(1989), nr 3, s. 248-259.

Pruss W., Społeczeństwo Królestwa Polskiego w XIX i początkach XX wieku, cz. 1, Narodowości, wyznania, sekty, organizacje kościelne, „Przegląd Historyczny” 68(1977), nr 2, s. 259-288.

RÓŻAŃSKI J., Główne dziedziny inkulturacji, „Studia Theologica Varsaviensia” 49(2011), nr 2, s. $43-78$.

RÜTHER K., Der Streit um Englisch als Unterrichtsfach im lutherischen Missionsschulen Südafrikas (1895-1910). Impulse für eine Geschichte, [w:] Mission Global, red. R. Habermas, R. Hölzl, Böhlau: Böhlau Verlag 2014, s. 91-110.

Sosnowska J., Działalność duszpasterska i społeczna pastora Rudolfa Gustawa Gundlacha (1850-1922). Przyczynek do historii dobroczynności w Łodzi, „Studia z Historii Społeczno-Gospodarczej XIX i XX Wieku” 10(2012), s. 87-103.

SzKUTNIK P., Sprowadzanie użytecznych cudzoziemców. Osadnicy w zachodniej części Królestwa Polskiego w pierwszej połowie XIX wieku na przykładzie przodków autora, „Kwartalnik Historii Kultury Materialnej” 2013, nr 3, s. 409-422.

Szlanta P., Opinia publiczna Królestwa Polskiego wobec wojny burskiej, „Przegląd Historyczny" 91(2000), nr 4, s. 535-550.

ZINS H., Cecil Rhodes i powstanie protektoratu Beczuany w 1885 roku, „Annales Universitatis Mariae Curie-Skłodowska", Sectio F, 1997/1998, t. 52/53, s. 225-236.

ZINS H., Cecil Rhodes. Ekspansja brytyjska w Afryce pod koniec XIX wieku, Gdańsk: Polnord. Wydawnictwo Oskar 2000. 
ŻUKOwsKi A., Polskie nazwy w Afryce Południowej (na tle nazewnictwa pochodzenia europejskiego), „Poradnik Językowy” 1996, z. 3, s. 57-63.

\title{
Strony internetowe
}

https://medium.com/@penzhorn.waldo_1942/the-hermannsburg-mission-f0a951f5cf04

http://old.luteranie.pl/pl/index.php?D=631

https://www.safrika.org/Pics/Tvl-map-01.gif

\author{
STACJA MISYJNA „POLONIA” W TRANSWALU (1885-1914) \\ NA PODSTAWIE PRASY KOŚCIOŁA EWANGELICKO-AUGSBURSKIEGO \\ W KRÓLESTWIE POLSKIM
}

\author{
Streszczenie
}

„Dźwignij brzemię białego człowieka...” - te słowa słynnego utworu Rudyarda Kiplinga (The White Man's Burden) stanowiły swoisty sztandar ideowy XIX-wiecznych państw kolonialnych. Jednak, jak wiadomo, rzeczywistość daleka była od wspominanego w tymże utworze służenia, a imperia europejskie nie wysyłały „swych najlepszych synów” po to, by otaczali rdzenną ludność troskliwą opieką.

W tych realiach tym bardziej interesujące stają się postawy osób, które - poniekąd wbrew mentalności epoki - starały się dostrzegać podmiotowość plemion i społeczności tubylczych, chciały przekonywać, a nie zmuszać do zmian. Do nich zaliczyć należy twórców i pracowników stacji misyjnej „Polonia”, prowadzonej w ramach współpracy Kościoła Ewangelicko-Augsburskiego w Królestwie Polskim z misją hermannsburską. Placówka położona była w Afryce Południowej, $30 \mathrm{~km}$ na północny zachód od Pretorii i utrzymywała się dzięki składkom wiernych. Ta inicjatywa stosunkowo niewielkiej społeczności luterańskiej ziem polskich zaboru rosyjskiego pozostaje niemal nieznana.

Słowa kluczowe: Kościoły protestanckie; Transwal (prowincja w Afryce Południowej); stacja misyjna „Polonia”

\section{THE POLONIA MISSION STATION IN THE TRANSVAAL REPUBLIC (1885-1914) AS COVERED IN THE PRESS OF THE LUTHERAN CHURCH IN THE KINGDOM OF POLAND}

Summary

"Take up the White Man's burden...," these words from of the well-known poem by Rudyard Kipling created a specific ideological banner wielded by the 19th-century colonial states. However, it is common property that the reality was far from the idea of service espoused by the poet, and the European empires did not "send forth the best ye breed" to attend to the needs of indigenous peoples.

In that reality, particularly noteworthy were the attitudes of individuals who, somewhat contrary to the contemporary mindset, sought to recognise the subjectivity of indigenous tribes and 
communities and wished to encourage them to change rather than imposing anything. Some of such individuals were the founders and staff of the Polonia Mission Station operated as a splinter of cooperation between the Lutheran Church in the Kingdom of Poland and the Hermannsburg Mission. The facility was located in South Africa, $30 \mathrm{~km}$ northwest of Pretoria, and operated thanks to contributions from the faithful. This initiative of the relatively small Lutheran community in the Polish territory under the Russian rule remains almost unknown.

Słowa kluczowe: Lutheran Church; Transvaal (South Africa); Polonia Mission Station 